\title{
Kadar kelarutan fluor Glass Ionomer Cement setelah perendaman air sungai dan akuades
}

\author{
Phradina Fili Septishelya*, Muhammad Yanuar Ichrom Nahzi**, Nurdiana Dewi ${ }^{\star * *}$ \\ *Program Studi Kedokteran Gigi, Fakultas Kedokteran Gigi, Universitas Lambung Mangkurat, Banjarmasin, Kalimantan Selatan, \\ Indonesia \\ **Bagian Konservasi Gigi, Fakultas Kedokteran Gigi, Universitas Lambung Mangkurat, Banjarmasin, Kalimantan Selatan, Indonesia \\ ***Bagian Biologi Mulut, Fakultas Kedokteran Gigi, Universitas Lambung Mangkurat, Banjarmasin, Kalimantan Selatan, Indonesia \\ *JI Veteran 128B, Banjarmasin, Kalimantan Selatan, Indonesia; e-mail: shelyfili@gmail.com
}

Submisi: 26 April 2016; Penerimaan: 26 Mei 2016

\begin{abstract}
ABSTRAK
Glass lonomer Cement (GIC) merupakan bahan restorasi yang memiliki sifat adhesif, sewarna dengan gigi dan memiliki kemampuan pelepasan ion fluor yang dipengaruhi derajat keasaman $(\mathrm{pH})$. Air sungai Desa Anjir Pasar memiliki sifat yang asam dengan $\mathrm{pH}$ 3. Derajat keasaman $(\mathrm{pH})$ asam dapat meningkatkan kadar kelarutan ion fluor pada GIC. Tujuan penelitian ini untuk mengetahui perbedaan kadar kelarutan ion fluor pada GIC setelah perendaman dalam air sungai Desa Anjir Pasar dan akuades. Penelitian ini menggunakan sampel GIC dengan diameter $5 \mathrm{~mm}$ dan ketebalan $2 \mathrm{~mm}$. Masing-masing kelompok direndam dalam air sungai dan akuades selama 7 hari kemudian dihitung kadar kelarutan ion fluornya. Data diuji menggunakan analisis parametrik Independent T-Test $95 \%(\alpha=0,05)$ dan didapatkan $p=0,002$ $(p<0,05)$. Dari hasil tersebut diketahui bahwa terdapat perbedaan bermakna antara kadar kelarutan ion fluor setelah perendaman air sungai dengan kadar kelarutan ion fluor setelah perendaman akuades. Disimpulkan bahwa terdapat perbedaan yang signifikan antara kadar kelarutan ion fluor pada GIC setelah perendaman dalam air sungai Desa Anjir Pasar Barito Kuala yang lebih tinggi daripada setelah perendaman dalam akuades.
\end{abstract}

Kata kunci: akuades, air sungai, GIC, kadar kelarutan ion fluor

\begin{abstract}
The Level of Fluor Solubility of Glass lonomer Cement after submergence in the river water and aquadest GIC (GIC) is a restoration material that has a number of adhesive characteristics, tooth-coloured, and can release fluoride ion influenced by $\mathrm{pH}$. The river water of Anjir Pasar village has acidic nature with $\mathrm{pH}$ as low 3. Acid $\mathrm{pH}$ can increase Fluor ion solubility in GIC. The aim of the study was to find difference of fluor ion solubility of GIC after submergence in the river water and aquadest. This study used GIC samples with the diameter of $5 \mathrm{~mm}$ and thickness of $2 \mathrm{~mm}$. One group was soaked in river water and another group was soaked in aquadest for 7 days before conducting the measurement of the fluor ion solubility. The data were analysed by parametric Independent T-Test $95 \%(\alpha=0.05)$ and it was found $p$ value $=0.002(p<0.05)$. The result indicated a significant difference of fluor ion solubility between GIC after submergence in river water and aquadest. It can be concluded that there is a significant difference of fluor ion solubility of GIC in which submergence in the river water was found higher than that of aquadest.
\end{abstract}

Keywords: aquadest, GIC, fluor ion solubility, river water

\section{PENDAHULUAN}

Kesehatan gigi dan mulut secara tidak langsung menjadi bagian penting dan tidak dapat dipisahkan dari kesehatan tubuh secara umum sehingga merupakan investasi seumur hidup. Penyakit gigi dan mulut yang paling banyak ditemukan di masyarakat luas yaitu karies gigi, karies tidak hanya terjadi pada orang dewasa tetapi dapat pula terjadi pada anak. ${ }^{1}$ Salah satu cara penanggulangan karies adalah dengan membuang jaringan karies dan menumpatnya dengan bahan restorasi. Bahan restorasi berfungsi untuk memperbaiki dan merestorasi struktur gigi yang rusak. ${ }^{2}$ Bahan yang sering digunakan untuk merestorasi baik gigi sulung maupun gigi tetap dalam praktek kedokteran gigi adalah bahan restorasi adhesif sewarna gigi. Bahan restorasi sewarna gigi yang banyak beredar di pasaran salah satunya adalah Glass Ionomer Cement (GIC). ${ }^{3}$

Bahan GIC yang pertama kali diperkenalkan pada bidang kedokteran gigi oleh Wilson dan Kent tahun $1972 .{ }^{4}$ Mereka menggabungkan keunggulan sifat translusen dan pelepasan ion fluor dari semen silikat serta biokompatibilitas dan sifat adhesif dari 
semen polikarboksilat. GIC pada awalnya hanya diindikasikan untuk restorasi karies servikal atau lesi abrasi karena tekanan mekanis yang rendah. GIC terus mengalami perbaikan dalam beberapa sifat fisik dan mekanik dalam upaya untuk memperluas aplikasi GIC dalam bidang kedokteran gigi. ${ }^{5}$ Terdapat beberapa jenis GIC berdasarkan penggunaannya, tipe I untuk material perekat, tipe II untuk material restorasi dan tipe III untuk basis atau pelapis. GIC tipe II secara umum mempunyai sifat lebih keras dan kuat dibandingkan tipe I, karena mempunyai rasio bubuk terhadap cairan lebih tinggi. Material ini amat berguna dalam merawat pasien gigi anak yang mempunyai risiko karies tinggi karena melepas fluor dan estetik dapat diterima, juga untuk restorasi kelas III dan $\mathrm{V}$ pada dewasa. ${ }^{6}$

Bahan GIC terdiri dari bubuk dan cairan. Bubuk pada GIC adalah kaca calcium fluoroaluminosilicate terdiri dari Silica $\left(\mathrm{SiO}_{2}\right)$, Alumina $\left(\mathrm{Al}_{2} \mathrm{O}_{3}\right)$, Aluminium Fluoride $\left(\mathrm{AlF}_{3}\right)$, Calcium Fluoride $\left(\mathrm{CaF}_{2}\right)$, Natrium Fluoride (NaF), dan Aluminium Fosfat $\left(\mathrm{AlPO}_{4}\right)$ yang larut dalam cairan asam. Lanthanum, stronsium, barium, dan oksida seng ditambahkan untuk mendapatkan sifat radioopak. Cairan GIC adalah cairan dari asam poliakrilat dengan konsentrasi 40$50 \%{ }^{7}$

Bahan GIC memiliki sifat adhesif dan mampu melepaskan ion fluor. ${ }^{8}$ Pada GIC terdapat 10 hingga $23 \%$ ion fluor. ${ }^{9}$ Ion fluor terletak di dalam matriks yang dilepaskan dari bubuk kaca pada saat pencampuran bubuk dan cairan. Bubuk dan cairan dari GIC bercampur, reaksi setting dimulai dengan pelepasan ion fluor dari bubuk dengan ion kalsium dan aluminium untuk membangun matriks semen sebagai ion, garam dan gel. Pada GIC yang baru saja setting memiliki kandungan fluor lebih banyak daripada kandungan fluor di gigi. Hal ini menyebabkan terjadinya difusi ion fluor dari GIC ke gigi dengan membentuk kristal fluoroapatite untuk membantu gigi melawan proses terjadinya karies gigi. ${ }^{10}$ Bahan restoratif yang memiliki kemampuan pelepasan ion fluor dapat mengurangi terjadinya demineralisasi gigi di sekitar restorasi. Bahan restorasi GIC menunjukkan efektivitas yang lebih besar daripada bahan restorasi berbasis resin. ${ }^{11}$ Ion fluor mampu mengurangi demineralisasi email dengan mengubah hidroksiapatit dalam gugus email menjadi fluorapatit yang lebih tahan terhadap asam. ${ }^{12}$ Pelepasan ion fluor dari bahan restorasi dipengaruhi oleh faktor intrinsik dan faktor ekstrinsik, salah satu dari faktor ekstrinsiknya adalah $\mathrm{pH} .{ }^{13}$

Pada penelitian Kiran, didapatkan GIC pada perendaman dalam air yang bersifat asam $(\mathrm{pH}$ rendah) melepas ion fluor lebih banyak daripada perendaman dalam air dengan $\mathrm{pH}$ netral. ${ }^{14}$ Kondisi air sungai di Barito Kuala kebanyakan memiliki sifat yang asam. Hasil dari analisa pemeriksaan sampel air oleh Laboratorium Instalasi Pengolahan Air Minum PDAM Bandarmasin, air sungai yang terdapat di daerah Desa Anjir Pasar, Kabupaten Barito Kuala memiliki kondisi yang cukup asam yaitu dengan $\mathrm{pH} 4,00 .{ }^{15}$ Pada penelitian Permatasari, didapatkan $\mathrm{pH}$ air sungai Desa Anjir Pasar Barito Kuala yaitu 4,07. Masyarakat di Kalimantan Selatan masih banyak yang menggunakan air sungai sebagai sumber air bersih khususnya air sungai yang berada di Barito Kuala. ${ }^{16}$ Data yang didapatkan dari Riskesdas tahun 2008, air-air yang mengalir di Kabupaten Barito Kuala, seperti di Desa Anjir Pasar, Kalimantan Selatan kondisinya paling keruh, berasa, berbau, dan berwarna daripada kabupaten lainnya. ${ }^{17}$ Berdasarkan laporan program pelayanan kesehatan gigi dan mulut yang didapatkan dari puskesmas Anjir Pasar, masyarakat Desa Anjir Pasar masih banyak yang mengalami karies gigi dan umumnya dilakukan restorasi menggunakan bahan GIC.

Berdasarkan uraian di atas, peneliti ingin mengetahui perbedaan kadar kelarutan ion fluor pada GIC setelah perendaman air sungai Desa Anjir Pasar Barito Kuala dan akuades. Penelitian ini diharapkan dapat memberikan informasi mengenai pengaruh air sungai Desa Anjir Pasar Barito Kuala terhadap kadar kelarutan ion fluor pada GIC dan dapat digunakan sebagai pertimbangan bagi dokter gigi dalam penggunaan GIC sebagai bahan tambal.

\section{METODE PENELITIAN}

Penelitian dilaksanakan pada bulan Agustus 2015 di Laboratorium Biokimia Fakultas Kedokteran Universitas Lambung Mangkurat Banjarbaru. Penelitian ini merupakan penelitian eksperimental 
murni (true experimental) dengan rancangan posttest only with control group design. Penelitian menggunakan simple random sampling terdiri dari 3 kelompok yaitu kelompok tanpa dilakukan perendaman, kelompok dengan perendaman air sungai Desa Anjir Pasar Barito Kuala pH 3 dan kelompok dengan perendaman akuades. Cara menentukan jumlah sampel dalam penelitian ini menggunakan rumus Lemeshow.

Penelitian ini diawali dengan pengambilan sampel air sungai menggunakan water sampler di bagian tengah air sungai ( $1 / 2$ dari lebar dan kedalaman sungai), kemudian disimpan dalam botol. Air sungai dihitung $\mathrm{pH}$-nya menggunakan alat $\mathrm{pH}$ meter. Setelah itu, pembuatan bahan sampel GIC. Proses diawali dengan pencampuran bubuk dan cairan sesuai aturan pabrik dan dimasukkan ke dalam cetakan. Cetakan diberi alas celluloid strip yang diletakkan di atas glass lab. Agar permukaan bahan rata dan halus, ditutup dengan celluloid strip selama sepuluh menit. Setelah mengeras celluloid strip dilepas dari permukaan bahan tersebut. Selanjutnya kelebihan GIC dapat dikurangi menggunakan scalpel dan sampel dikeluarkan dari cetakan. Sampel disimpan dalam cawan petri dan diletakkan dalam inkubator $37^{\circ} \mathrm{C}$ selama 24 jam agar terjadi reaksi setting yang sempurna.

Setelah sampel GIC setting, sampel dikeluarkan dari inkubator. Pada sampel tanpa perendaman dilakukan pengukuran kadar ion fluor secara langsung sedangkan pada sampel perlakuan dimasukkan ke dalam gelas beker berisi air sungai dan sebagian ke dalam gelas beker berisi akuades. Sampel disimpan di dalam inkubator dengan suhu $37{ }^{\circ} \mathrm{C}$ selama 7 hari. Setelah 7 hari perendaman, sampel dikeluarkan dengan pinset. Sampel digerus menggunakan mortar hingga halus dan dimasukan ke dalam $100 \mathrm{~mL}$ gelas kimia kemudian diencerkan $10 \mathrm{~mL}$ akuades dan $10 \mathrm{~mL}$ buffer natrium fluorida. Setelah itu, dilakukan pengukuran kadar ion fluor dengan cara merendam elektroda ke dalam larutan sampel selama 3 menit menggunakan alat $\mathrm{pH}$ meter (Lutron $\mathrm{pH}-208$ ). Alat $\mathrm{pH}$ meter yang digunakan memiliki skala milivolt untuk mengetahui kekuatan ionik dari sampel menggunakan elektroda ion selektif. Elektroda dikalibrasi menggunakan larutan standar fluoride $5 \mathrm{ml}, 10 \mathrm{ml}, 20 \mathrm{ml}$ yang dicampur larutan buffer dengan volume yang sama kemudian elektroda dimasukan ke dalam larutan ini dan diperoleh hasil yang dapat dibaca pada instrumen. Hasil konsentrasi fluor dikonversi dari satuan milivolt ke ppm sehingga setiap hasil konsentrasi ion fluor dihitung dalam satuan ppm.

Data yang didapat dari penelitian ini berupa data kuantitatif kadar kelarutan ion fluor yang dihitung pada kelompok sampel tanpa perendaman dikurangi dengan kadar ion fluor pada kelompok sampel yang dilakukan perendaman akuades dan air sungai. Hasilnya didapatkan 2 kelompok kelarutan ion fluor yang terdiri dari kelompok kelarutan ion fluor setelah perendaman akuades dan kelompok kelarutan ion fluor setelah perendaman air sungai. Setelah didapatkan hasil kuantitatif kemudian dilakukan tabulasi, coding dan editing data yang selanjutnya akan dilakukan uji data statistik.

Distribusi data dievaluasi secara statistik dengan melakukan uji normalitas Shapiro-Wilk test dan data keragaman dilakukan uji homogenitas Levene's test. Selanjutnya jika data terdistribusi normal dan homogen maka dilakukan analisis data uji parametrik dengan menggunakan uji hipotesis Independent $t$-test. Tingkat kepercayaan sebesar $95 \%(\alpha=0,05)$.

\section{HASIL PENELITIAN}

Berdasarkan penelitian yang telah dilakukan, rata-rata kadar kelarutan ion fluor pada GIC setelah perendaman air sungai dan akuades dapat dilihat pada Gambar 1.

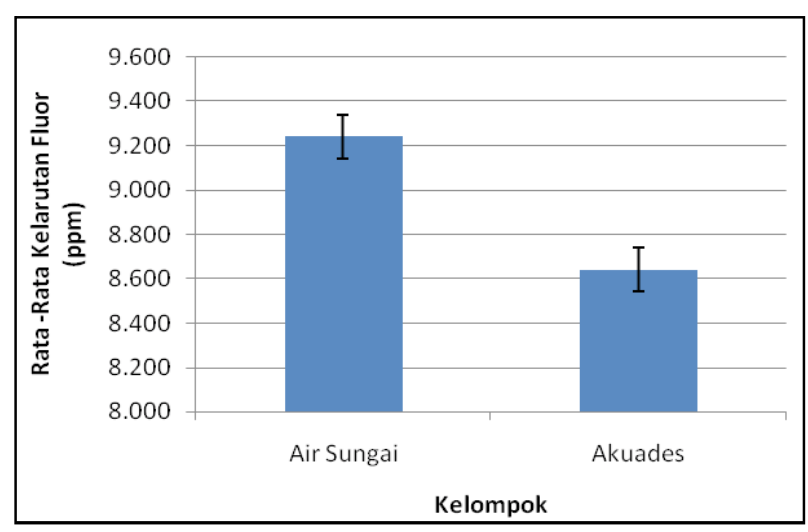

Gambar 1. Kadar kelarutan ion fluor pada GIC setelah perendaman air sungai Desa Anjir Pasar dan akuades 
Berdasarkan data di atas dapat dilihat bahwa kadar kelarutan ion fluor pada GIC setelah perendaman air sungai memiliki nilai yang lebih tinggi yaitu $(9,241 \pm 0,101) \mathrm{ppm}$ dibandingkan kadar kelarutan ion fluor setelah perendaman akuades dengan nilai $(8,641 \pm 0,275) \mathrm{ppm}$. Analisis data dimulai dari uji normalitas Shapiro-Wilk. Hasil yang didapatkan dari uji normalitas pada kelarutan ion fluor pada kelompok kelarutan ion fluor setelah perendaman air sungai, didapatkan data dengan nilai $p=0,928$. Pada kelompok kelarutan ion fluor setelah perendaman akuades, didapatkan data dengan nilai $p=0,325$. Hasil uji normalitas pada kelompok kelarutan ion fluor setelah perendaman air sungai dan akuades memiliki nilai $p>0,05$. Hal ini berarti kedua data terdistribusi normal. Analisis data dilanjutkan dengan menggunakan Levene's test untuk mengetahui homogenitas data. Berdasarkan uji homogenitas pada kelarutan ion fluor didapatkan $p=0,86(p>0,05)$ sehingga data homogen.

Setelah didapatkan data normal dan homogen maka untuk mengetahui perbedaan yang bermakna dari hasil penelitian ini, dilanjutkan analisis data menggunakan uji parametrik Independent T-test. Hasil dari analisis data Independent $t$-test didapatkan $p=0,002 \quad(p<0,05)$ sehingga Ho ditolak. Hasil penelitian mengindikasikan terdapat perbedaan yang bermakna antara kadar kelarutan ion fluor pada GIC setelah perendaman dalam air sungai Desa Anjir Pasar Kabupaten Barito Kuala dibandingkan dengan akuades.

\section{PEMBAHASAN}

Pada hasil pengukuran, ion fluor pada GIC mengalami kelarutan setelah perendaman dalam akuades dan air sungai. Hal ini kemungkinan disebabkan oleh sifat sensitifitas air yang dimiliki GIC. Sifat sensitifitas GIC terhadap air yang dapat mempengaruhi struktur mikro, kelarutan serta daya adhesi pada bahan restorasi dengan permukaan gigi akan menurun. GIC mengandung silica hidrogel yang terbentuk di sekitar partikel kaca saat proses setting berlangsung yang memiliki sifat hidrofilik yaitu mudah berikatan atau terserap oleh air. ${ }^{18}$ Penyerapan air ke dalam bahan restorasi GIC melibatkan penetrasi molekul cairan ke dalam struktur dari bahan restorasi secara difusi. Penyerapan air dapat meningkatkan volume bahan restorasi, menyebabkan kerusakan struktur matriks dan kelarutan komponen dari bahan restorasi. ${ }^{19}$

Pada hasil pengukuran rata-rata kadar kelarutan ion fluor pada GIC setelah dilakukan perendaman dalam air sungai mengalami kelarutan yang lebih tinggi dibandingkan dengan kadar kelarutan ion fluor setelah dilakukan perendaman dalam akuades. Hal ini kemungkinan disebabkan oleh $\mathrm{pH}$ asam yang dimiliki pada air sungai yaitu $\mathrm{pH} 3$. Air sungai mengandung besi dan sulfur yang akan membentuk besi-sulfida (FeS). Besi sulfida akan bereaksi dengan elemen sulfur menjadi $\left(\mathrm{FeS}_{2}\right)$ yang disebut pirit. Pirit dalam keadaan aerob akan teroksidasi menghasilkan ion hidrogen dan ion sulfat. Setiap molekul pirit yang teroksidasi akan membebaskan 4 molekul ion hidrogen. Oksidasi pirit inilah yang akan menyebabkan air sungai bersifat asam..$^{20}$ Ketika suatu asam berada dalam air, maka ion hidrogen yang terdapat di dalam air sungai ini terionisasi sehingga akan banyak ion hidrogen yang terbebas. ${ }^{21}$ Ion hidrogen $\left(\mathrm{H}^{+}\right)$bebas yang terdapat dalam cairan asam akan memutuskan ikatan ikatan ion dan menyebabkan terjadinya kelarutan dalam bahan restorasi. ${ }^{16}$ Mulanya air dan ion hidrogen berdifusi masuk ke dalam bahan restorasi GIC, hal ini menyebabkan terjadinya pelepasan ion fluor di dalam bahan restorasi, kemudian ion fluor berdifusi keluar dari bahan restorasi GIC dan ikut terlarut dalam air. ${ }^{22} \mathrm{GIC}$ melepaskan ion fluor lebih banyak pada lingkungan $\mathrm{pH}$ rendah, sehingga menghasilkan jumlah ion fluor lebih besar yang dibutuhkan untuk mencegah karies sekunder. ${ }^{14}$

\section{KESIMPULAN}

Dari penelitian ini dapat disimpulkan bahwa terdapat perbedaan yang signifikan antara kadar kelarutan ion fluor pada GIC setelah perendaman dalam air sungai Desa Anjir Pasar Barito Kuala yang lebih tinggi daripada setelah perendaman dalam akuades. Saran yang dapat diberikan setelah dilakukannya penelitian ini adalah perlunya penelitian lebih lanjut mengenai kadar kelarutan ion lain selain fluor pada GIC dilakukan perendaman dalam air sungai Desa Anjir Pasar serta kandungan 
air sungainya agar dapat mengetahui faktor lain yang dapat mempengaruhi kelarutan ion pada GIC, perlunya penelitian lebih lanjut mengenai kadar kelarutan ion fluor pada GIC secara in vivo kepada manusia agar hasil dapat sesuai dengan keadaan rongga mulut.

\section{DAFTAR PUSTAKA}

1. Wala HC, Wicaksono DA, Tambunan E. Gambaran status karies gigi anak usia 11-12 tahun pada keluarga pemegang jamkesmas di kelurahan Tumatangtang I kecamatan Tomohon Selatan. Jurnal e-Gigi. 2014; 2(1): 3.

2. Hakim R, Lampus B, Wowor VNS. Gambaran tumpatan Glass lonomer Cement pada mahasiswa akademi keperawatan rumah sakit tingkat III Robert wolter mongonsidi. Jurnal e-Gigi. 2013; 1(2): 2.

3. Yuliarti RT, Suwelo IS, Soemartono SH. Kandungan unsur fluor pada email gigi tetap muda dengan tumpatan semen ionomer kaca viskositas tinggi. Indonesian Journal of Dentistry. 2008; 15(2): $163-168$.

4. Iz GS, Ertugrul F, Eden E, Gurhan SI. Biocompatibility of Glass lonomer Cement $S$ with and without chlorhexidine. Europe Journal Dental. 2013; 7: 89 - 93.

5. AlJamhan AS. In-vitro wear and hardness of new conventional Glass lonomer Cement coated with nano-filled resin. Indiana University School of Dentistry; 2011. 5-7.

6. Meizarini A, Irmawati. Kekerasan permukaan semen ionomer kaca konvensional tipe II akibat lama penyimpanan. Dental Jurnal. 2005; 38(3): 146 - 150.

7. Fitriyana DC, Pangemanan DHC, Juliatri. Uji pengaruh saliva buatan terhadap kekuatan tekan semen ionomer kaca tipe II yang direndam dalam minuman isotonik. Jurnal e-GiGi (eG). 2014; 2(2): 1 - 7.

8. Mount GJ, Hume WR. Preservation and restoration of tooth structures $2^{\text {nd }}$ ed. Australia: Knowledge Books and Software; 2005. 21 29.
9. Garg N, Garg A. Textbook of Operative Dentistry $2^{\text {nd }}$ ed. Jaypee Brothers Medical Publishers; 2013. 480 - 481.

10. Elizabeta G, John NW, Snezana I, lan S. The potential of fluoride-releasing dental restoratives to inhibit enamel demineralization: an sem study. Contributions, Section Biology Medical Science, XXX, 2009: 1: 191 - 203.

11. Dionysopoulos D, Thessaloniki, Greece. The effect of fluoride-releasing restorative materials on inhibiton of secondary caries formation. Research Review Fluoride 2014; 47(3): $258-265$.

12. Indahyani DE, Sulistyani, Raharjo R. Pengaruh bahan pit dan fissure silen glass ionomer terhadap dekalsifikasi email. Dentika Dental Journal 2004; 9(1): 1 - 5 .

13. Hegde MN, Susan JJ, Darshana D, Hegde Nidarsh D. Effect of daily fluoride exposure on fluoride release by high strength glass ionomer restorative material used with atraumatic restorative technique: an in vitro study. International Research Journal of Pharmacy. 2012; 3(4): 241 - 246.

14. Kiran A, Hegde V. A short comparitive analysis of fluoride release from a newly introduced GIC in deionised water and lactic acid. Journal International Oral Health. 2010; 2(2): 71 - 78.

15. Fatria AA, Sukmana BI, Cholil. Perbandingan angka karies pada remaja yang mengkonsumsi air sungai dan air pdam di Desa Anjir Pasar Kota Kabupaten Barito Kuala. Jurnal Kedokteran Gigi Dentino. 2013; 1(2): 238 244.

16. Permatasari AP. Kekasaran permukaan resinmodified Glass lonomer Cement setelah perendaman dalam air sungai Desa Anjir Pasar. Diajukan pada seminar skripsi Fakultas Kedokteran Universitas Lambung Mangkurat, Desember 2014, Banjarmasin. 25

17. Profil kesehatan provinsi kalimantan selatan tahun 2007. Hasil Riset Kesehatan Dasar (RISKESDAS) Provinsi Kalimantan Selatan. Jakarta: Badan Penelitian dan Pengembangan Kesehatan Departemen Kesehatan RI, 2008. 
18. Aviandani MJ, Munadziroh E, Yogiartono M. Perbedaan kebocoran tepi tumpatan semen ionomer kaca dengan pengadukan secara mekanik elektrik dan manual. Jurnal PDGI. 2009; 61(3): 81 - 87.

19. Dinakaran S. Sorption and solubility characteristics of compomer, conventional and resin modified glass-ionomer immersed in various media. IOSR Journal of Dental and Medical Sciences. 2014; 13(3): 41 - 45.

20. Noor M. Pertanian lahan gambut, potensi dan kendala. Yogyakarta: Kansius; 2001. $74-75$.
21. Anggraini R, Yogyarti $S$, Harijanto E. Kekerasan permukaan semen ionomer kaca konvensional dan modifikasi resin setelah perendaman dalam minuman cola. Material Dental Journal. 2011; 2(1): $26-30$.

22. Nigam AG, Jaiswal JN, Murthy RC, Pandey RK. Estimation of fluoride release from various dental material in different media an in vitro study. International Scientific Journals from Jaypee. 2009; 2(1): 1 - 8 . 